\title{
Study of association of socio-demographic characteristics with the knowledge about sex determination and preconception and prenatal diagnostic technique act among pregnant women
}

\author{
Seema Dwivedi, Garima Gupta*, Sudha Kumari, Bandana Sharma
}

Department of Obstetrics and Gynaecology, GSVM Medical College, Kanpur, Uttar Pradesh, India

Received: 06 June 2021

Accepted: 05 July 2021

\section{*Correspondence:}

Dr. Garima Gupta,

E-mail: amitygarima@gmail.com

Copyright: ( $)$ the author(s), publisher and licensee Medip Academy. This is an open-access article distributed under the terms of the Creative Commons Attribution Non-Commercial License, which permits unrestricted non-commercial use, distribution, and reproduction in any medium, provided the original work is properly cited.

\section{ABSTRACT}

Background: Preconception and prenatal diagnostic technique Act was amended in year 2003 which provides for prohibition of sex selection before and after conception and for regulation of prenatal diagnostic technique.

Methods: A cross sectional study was carried out in antenatal ward of GSVM Medical College Kanpur during the period of January to December 2019. A total of 2500 pregnant women were included and predesigned and pretested questionnaire was used to get information regarding socio-demographic details of pregnant women. They were asked regarding the knowledge and attitude towards the PC-PNDT Act. Data were collected and analyzed using Microsoft excel and Statistical package for social sciences (SPSS)-12.

Results: In the present study, out of 2500 women, 2125 (85\%) knew about sex determination while $125(5 \%)$ knew about PNDT Act. There was significant association of occupation, education and annual income with knowledge. Majority of women know about PC-PNDT act from health staff and ultrasonography was the main technique they know to detect sex determination.

Conclusions: The falling ratio of girl child is a matter of grave concern. Effective implementation of the PNDT Act in addition to spreading awareness about this act among people is the need of the hour. Educating the community will prevent the decline in sex ratio and female feticide through PC-PNDT Act.

Keywords: Attitude, Knowledge, Prenatal diagnostic act

\section{INTRODUCTION}

"Female foeticide is bio-terrorism, it is even worse than genocide."

In country like India where female are worshipped as goddess, crime against women starts in womb itself. As per the census, 2011 the child sex ratio (0-6 years) has shown a decline from 927 females per thousand males in 2001 to 919 females per thousand males in 2011. ${ }^{1}$ The arrival of prenatal diagnosis in 1970s was hailed as scientific miracles but instead it became a tool for selective female foeticide after abortion was legalized especially in urban areas. ${ }^{2,3}$ In early 1980's ultrasound method which was non-invasive and economical was introduced. It was black day in history of advertisement when Ultrasound was advertised on billboards of India stating-"Invest rupees 500 now, save Rs 50,000 later" to encourage parents to abort female fetus and save future dowry. ${ }^{4}$ In last two decades in India some 10 million female fetus are estimated to have been aborted. ${ }^{5}$ Due to easy availability people have misused the technology. Easy availability of MTP as over the counter drugs, illegally without doctor's prescription has increased this social evil of female foeticide drastically. In order to curb this horrendous trend Indian Parliament has enacted the controversial PC-PNDT 
Act in 1994 which prohibits sex selection and regulates prenatal diagnostic techniques to prevent them misuse. This draconian law has been misused against doctors in form of punishment for even clinical errors. But our main point of contention to carry this study to emphasize that doctors only are not culprit for female foeticide. The family involved is too liable for punishment which should have made clear in public so that they fear law before when thinking about female foeticide.

According to this law, no laboratory or centre or clinic will conduct any test including ultrasonography for the purpose of determining the sex of the foetus. No person, including the one who is conducting the procedure as per the law, will communicate the sex of the foetus to the pregnant woman or her relatives by words, signs or any other method. The PC-PNDT Act is different from other social legislations because it does not involve only change in social behaviour and practices. It also demands ethical medical practice and the regulation of medical technologies that have the potential to be misused. The study principally aims to find out about the awareness regarding the Act and sex ratio and acknowledge its importance. The first and foremost aim of this act is to end the selective killing of girl's child form Prenatal sex determination (PSD) and established the good balance of sex ratio in India. Despite the above stated efforts, the fact leftovers that the child sex ratio is remaining to decline at an alarming rate. There are those who believe that changing the arrogance of the people rather than rigorous laws is the solution. However, changing cultural approaches is a massive challenge in a gigantic country like India with huge population and diverse languages. Fairly, it will need a lot of time and workout. Therefore, execution of the prevailing laws is, therefore, essential.

\section{METHODS}

A cross-sectional, hospital-based study was carried out during the period of January to December 2019 in GSVM Medical College. A study period of one year was considered.

All the women admitted during the study period were included. A total of 2500 pregnant women admitted in antenatal ward and who gave the consent for the study during the study period were selected consecutively and interviewed without any prompting. A pre-designed and pre-tested questionnaire was used to get information regarding socio-demographic details like age, education, socio-economic status and occupation of pregnant women. A pilot study was conducted by using a predesigned interview schedule to test the validity, applicability and practicability of the interview schedule and to assess the time required for the respondent to answer the questions. They were asked regarding the knowledge and attitude towards the PNDT Act. Knowledge of PNDT Act was assessed by asking regarding sex determination, the law and its punishment for misuse. Attitude was assessed by asking about the sex determination as a crime and thought of doing sex determination during pregnancy. Information given by the participants and their identity were kept confidential. The data collected were entered and analysed using the Microsoft excel and Statistical package for social sciences (SPSS)-12.

\section{RESULTS}

It was observed from Table 1 that out of total 2500 women, $1250(50 \%)$ women were in the age group of 20-30 years while $375(15 \%)$ were aged below 20 years.

Table 1: Distribution of pregnant women according to socio-demographic characteristics $(n=2500)$.

\begin{tabular}{|lll|}
\hline $\begin{array}{l}\text { Socio demographic } \\
\text { factors }\end{array}$ & $\begin{array}{c}\text { No. of } \\
\text { women }\end{array}$ & Percentage \\
\hline Age & \multicolumn{2}{l|}{} \\
\hline$<20$ years & 375 & $15 \%$ \\
\hline 20-30 years & 1250 & $50 \%$ \\
\hline$>30$ years & 875 & $35 \%$ \\
\hline Occupation & & \\
\hline Housewives & 2325 & $93 \%$ \\
\hline Service/ Employed & 175 & $7 \%$ \\
\hline Socioeconomic status & & \\
\hline Upper (I) & 75 & $3 \%$ \\
\hline Upper Middle (II) & 325 & $13 \%$ \\
\hline Lower middle (III) & 750 & $30 \%$ \\
\hline Upper Lower (IV) & 1000 & $40 \%$ \\
\hline Lower (V) & 350 & $14 \%$ \\
\hline Educational Status & & \\
\hline Illiterate & 375 & $15 \%$ \\
\hline Primary School (1-4) & 1625 & $65 \%$ \\
\hline Secondary School (5-10) & 250 & $10 \%$ \\
\hline Higher Secondary School & 250 & $15 \%$ \\
\hline & &
\end{tabular}

Majority of women were housewives 2325 (93\%) and 175 (7\%) were working women. According to modified B.G Prasad's Classification majority $1000(40 \%)$ belonged to upper lower class followed by $750(30 \%)$ belong to lower middle class while 350 (14\%) belong to lower class. About $1625(65 \%)$ had studied upto primary level schooling, 250 $(10 \%)$ upto secondary and $375(15 \%)$ upto higher secondary.

It was seen from Table 2 that out of 2500 women, 2125 $(85 \%)$ knew about sex determination while 375 (15\%) had no knowledge about sex determination. 1105 (52\%) told that sex determination can be done at private hospitals and $531(25 \%)$ told at government hospitals. Out of 2125 women, $1381(65 \%)$ told that sex determination can be done by sonography. A $956(45 \%)$ women regarding determining sex of the foetus as crime. Out of total 2500 women, only $125(5 \%)$ women knew about PNDT Act. Out of 125 , more than half women, $81(65 \%)$ only knew about PNDT Act from health staff. 2325 (93\%) women didn't know about the legal punishment for sex determination. 
Table 2: Assessment of the knowledge about PNDT Act among pregnant women.

\begin{tabular}{|lll|}
\hline Particulars & $\begin{array}{l}\text { No of women } \\
(\mathbf{n = 2 5 0 0})\end{array}$ & Percentage \\
\hline Do you know about sex determination? & 2125 & $85 \%$ \\
\hline Yes & 375 & $15 \%$ \\
\hline No & 1105 & \\
\hline Where sex determination can be done? (n=2125) & 531 \\
\hline Private Hospital & 489 & $25 \%$ \\
\hline Government Hospital & & $23 \%$ \\
\hline Don't Know & 1381 & \\
\hline Techniques used for sex determination. (n=2125) & 744 & $65 \%$ \\
\hline Sonography & & $35 \%$ \\
\hline Don't know & 956 & $45 \%$ \\
\hline Do you know that determining sex of child is a crime? & 1169 & $55 \%$ \\
\hline Yes & & \\
\hline No & 125 & $5 \%$ \\
\hline Do you know about PNDT Act? & 2125 & $85 \%$ \\
\hline Yes & & \\
\hline No & 25 & $20 \%$ \\
\hline Sources of information regarding PNDT Act? & 81 & $65 \%$ \\
\hline Massmedia (TV/ Radio/ Newspaper/ slogans/ hoardings) & 19 & $15 \%$ \\
\hline Health staff & & $7 \%$ \\
\hline Friends/ Relatives & 175 \\
\hline Is there any legal punishment for determining sex? & 2325 & $93 \%$ \\
\hline Yes &
\end{tabular}

Table 3: Assessment of the attitude about PNDT Act among pregnant women $(\mathbf{n}=\mathbf{2 5 0 0})$.

\begin{tabular}{|lll|}
\hline Particulars & Yes (\%) & No (\%) \\
\hline Do you think sex determination must be punished? & $96 \%$ & $4 \%$ \\
\hline $\begin{array}{l}\text { Are you willing to motivate people and spread awareness about } \\
\text { PNDT act? }\end{array}$ & $90 \%$ & $10 \%$ \\
\hline $\begin{array}{l}\text { Did you think that law against sex determination must be strictly } \\
\text { enforced? }\end{array}$ & $95 \%$ & $5 \%$ \\
\hline Sex determination of child should be done or not? & $94 \%$ & $6 \%$ \\
\hline $\begin{array}{l}\text { Do you feel correct that person (doctors, staff and relatives) } \\
\text { performing sex determination must be punished severely? }\end{array}$ & $97 \%$ & $3 \%$ \\
\hline
\end{tabular}

Table 4: Association of socio-demographic characteristics with the knowledge about sex determination and PNDT Act among pregnant women $(n=2500)$.

\begin{tabular}{|c|c|c|c|c|c|c|}
\hline \multirow{2}{*}{$\begin{array}{l}\text { Socio demographic } \\
\text { characteristics }\end{array}$} & \multicolumn{2}{|c|}{$\begin{array}{l}\text { Do you know about sex } \\
\text { determination }(\%)\end{array}$} & \multirow{2}{*}{$\begin{array}{l}\mathrm{X}^{2} \text {-value } \\
\mathrm{P} \text { value }\end{array}$} & \multicolumn{2}{|c|}{$\begin{array}{l}\text { Do you know about PNDT } \\
\text { Act }(\%)\end{array}$} & \multirow{2}{*}{$\begin{array}{l}X^{2} \text {-valuc } \\
\text { P value }\end{array}$} \\
\hline & Yes & No & & Yes & No & \\
\hline \multicolumn{7}{|l|}{ Age } \\
\hline$<20$ Years & 220 & 155 & \multirow{3}{*}{$\begin{array}{l}X^{2}=198.12 \\
P \text { value }= \\
0.00001 \\
D F=2\end{array}$} & 145 & 229 & \multirow{3}{*}{$\begin{array}{l}X^{2}=56.6 \\
P \text { value= } \\
0.00001 \\
D F=2\end{array}$} \\
\hline $20-30$ years & 1025 & 225 & & 392 & 675 & \\
\hline$>30$ years & 481 & 394 & & 554 & 505 & \\
\hline \multicolumn{7}{|l|}{ Education } \\
\hline Illiterate & 125 & 250 & $X^{2}=242.26$ & 94 & 281 & $X^{2}=85.5$ \\
\hline
\end{tabular}




\begin{tabular}{|c|c|c|c|c|c|c|}
\hline \multirow{2}{*}{$\begin{array}{l}\text { Socio demographic } \\
\text { characteristics }\end{array}$} & \multicolumn{2}{|c|}{$\begin{array}{l}\text { Do you know about sex } \\
\text { determination (\%) }\end{array}$} & \multirow{2}{*}{$\begin{array}{l}X^{2} \text {-value } \\
\text { P value }\end{array}$} & \multicolumn{2}{|c|}{$\begin{array}{l}\text { Do you know about PNDT } \\
\text { Act }(\%)\end{array}$} & \multirow{2}{*}{$\begin{array}{l}X^{2} \text {-value } \\
P \text { value }\end{array}$} \\
\hline & Yes & No & & Yes & No & \\
\hline Primary School (1-4) & 1095 & 530 & \multirow{3}{*}{$\begin{array}{l}P \text { value }= \\
0.00001 \\
D F=3\end{array}$} & 565 & 1059 & \multirow{3}{*}{$\begin{array}{l}\mathrm{P} \text { value }= \\
0.00001 \\
\mathrm{DF}=3\end{array}$} \\
\hline $\begin{array}{l}\text { Secondary School } \\
(5-10)\end{array}$ & 199 & 51 & & 51 & 199 & \\
\hline $\begin{array}{l}\text { Higher Secondary } \\
\text { School }\end{array}$ & 215 & 35 & & 139 & 112 & \\
\hline \multicolumn{7}{|l|}{ Occupation } \\
\hline Housewives & 1608 & 716 & \multirow{2}{*}{$\begin{array}{l}\mathrm{X}^{2}=10.2 \\
\mathrm{P} \text { value }= \\
0.00134 \\
\mathrm{DF}=1\end{array}$} & 332 & 1992 & \multirow{2}{*}{$\begin{array}{l}\mathrm{X}^{2}=333.3 \\
\mathrm{P} \text { value=} \\
0.00001 \\
\mathrm{DF}=1\end{array}$} \\
\hline Service/ Employed & 142 & 34 & & 122 & 54 & \\
\hline \multicolumn{7}{|l|}{ Socioeconomic status } \\
\hline Upper (I) & 75 & 4 & \multirow{5}{*}{$\begin{array}{l}X^{2}=170.5 \\
P \text { value }= \\
0.00001 \\
D F=2\end{array}$} & 5 & 70 & \multirow{5}{*}{$\begin{array}{l}X^{2}=211 . \\
P \text { value }= \\
0.0001\end{array}$} \\
\hline Upper Middle (II) & 436 & 64 & & 155 & 169 & \\
\hline Lower middle (III) & 529 & 221 & & 221 & 529 & \\
\hline Upper Lower (IV) & 686 & 489 & & 257 & 743 & \\
\hline Lower $(\mathrm{V})$ & 0 & 0 & & 5 & 346 & \\
\hline
\end{tabular}

It is evident from Table 3 that out of the 2500 women, 2400 (96\%) thought that sex determination must be punished. $2250(90 \%)$ women were willing to motivate people and spread awareness about PNDT act. 2375 (95\%) women thought that law against sex determination must be strictly enforced. 2350 (94\%) women said that sex determination should be done, while $150(6 \%)$ were against it. 2425 $(97 \%)$ women were of the opinion that person (doctor, staff and relatives) performing sex determination must be punished severely and 3\% told that they should not be punished.

It is evident from Table 4 that out of 2500 women, 1025 knew about sex determination in age group 20-30 years while out of them only 392 knew about PC-PNDT Act. Knowledge regarding sex determination and PNDT Act was significantly associated with education $(\mathrm{p}<0.01)$.

\section{DISCUSSION}

Skewed sex ratio is an issue of major concern and has long term social and demographic consequences. India is facing a demographic nightmare in terms of gender imbalance. In the present study, regarding the knowledge of these women on PNDT ACT, $2125(85 \%)$ knew about sex determination while only $125(5 \%)$ knew about PNDT Act. Similarly, a study by Shidhaye et al conducted at Mumbai revealed that $73.5 \%$ knew about sex determination while only $34.3 \%$ women knew about PNDT Act. A study by Shrivastava et al conducted at Bareilly revealed that $80 \%$ females were aware of prenatal sex determination and $67 \%$ unaware of PNDT Act. A study which was conducted by Ghose et al found that $95 \%$ of the pregnant women were aware of the availability of a method for intrauterine sex determination. When they were asked whether female foeticide was punishable, 53\% of the participants said that they were aware that doing so was punishable under the law. A study by Puri et al in slums of Chandigarh showed that only $11.66 \%$ of subjects had knowledge where sex determination can be done and $65.5 \%$ agreed to the fact that it is a crime, but only $16 \%$ were aware that it was punishable under the law. Chavada et al had similar findings with $91.1 \%$ of urban and $96.4 \%$ of rural women were aware of sex determination. Our study showed that $91.4 \%$ females told that sex determination can be done by sonography and maximum at private hospitals. Sonography as a technique for sex determination was done at private hospital was known to majority, $90 \%$ of women, as evident from Chavada et al study. ${ }^{10}$ Also they showed that persons who had undergone sex determination were the main source of information. Vadera et al showed that the awareness of consequences of female feticide grew with literacy status. Kansal et al also revealed that $84.5 \%$ respondents were aware that prenatal diagnostic tests are illegal. A study by Siddharam et al in his study, when they were asked regarding the various techniques which were used for prenatal sex determination, $73 \%$ participants said that ultrasound was the right modality, $6 \%$ said that it was amniocentesis and $19 \%$ said that they didn't know about the techniques. A study by Khandelwal et al revealed that though the knowledge regarding sex determination and PC and PNDT Act was present in women, still the practice of female feticide is prevalent in educated societies as their still remains a strong son preference in todays' society. ${ }^{14}$ 


\section{CONCLUSION}

It was observed in our study that participants were not aware about PCPNDT Act nor about aware of who could be punished under the act. Health Education should be given to the community regarding decline in sex ratio and PC and PNDT Act, and awareness should be given for utilization of newer modalities of prenatal diagnostic techniques, such as amniocentesis and genetic counselling for early detection of congenital anomalous rather than determining the sex of the child. It is important to make awareness on decline in sex ratio and importance of different legislatives acts to prevent female foeticide.

Funding: No funding sources

Conflict of interest: None declared

Ethical approval: The study was approved by the Institutional Ethics Committee

\section{REFERENCES}

1. Office of Registrar General and Census Commissioner, India. Population in age group 0-6 years by sex and sex ratio (0-6). Census of India, Government of India; 2011. Provisional population totals. http://www.censusindia.gov.in/2011-prov-res ults/indiaatglance.html. Accessed on 9th April, 2011.

2. Allahbadi GN. The 50 million missing women. J Assist Reprod Genet. 2002;19:411-6.

3. Madan $\mathrm{K}$, Breuning $\mathrm{M}$. Impact of prenatal technologies on the sex ratio in India: an overview. Genet Med. 2014;16:425-32.

4. Deshpande JD, Phalke DB, Phalke VD. Prenatal sex determination: issues and concerns. Pravara Med Review. 2009;4(1):4-6.

5. Jha P, Kumar R, Vasa P. Low female (corrected) -tomale (corrected) sex ratio of children born in India: National survey of 1.1 million households. Lancet. 2006;367:211-8.

6. Shidhaye PR, Giri PA, Nagaonkar, SN, Shidhaye RR. Study of knowledge and attitude regarding prenatal diagnostic techniques act among the pregnant women at a tertiary care teaching hospital in Mumbai. J Edu Health Promot. 2012;1.
7. Shrivastava S, Kariwal P, Kapilasrami MC. A community based study on awareness and perception on gender discrimination and sex preference among married women (in reproductive age group) in a rural population of district Bareilly, Uttar Pradesh. Nat J Commun Med. 2011;2:273-6.

8. Ghose S, Sarkar S. Knowledge and attitude of Prenatal Diagnostics techniques Act among the antenatal women- a hospital based study. J Community Med. 2009;5:1-6.

9. Puri S, Bhatia V, Swami HM. Gender preference and awareness regarding sex determination among married women in slums of Chandigarh. Indian $\mathbf{J}$ Community Med. 2007;32:60-2.

10. Chavada M, Bhagyalakshmi A. Knowledge, attitude and practice regarding sex determination among married women- a comparativestudy between urban and rural area. Indian $\mathbf{J}$ Matern Child Health. 2011;13:1-8.

11. Vadera BN, Joshi UK, Unadakat SV, Yadav BS, Yadav S. Study on Knowledge, attitude and practices regarding gender preference and female foeticide among pregnant women. Indian J Community Med. 2007;32:300-1

12. Kansal R, Khan AM, Bansal R, Parashar P. A hospital based study on knowledge, attitude and practice of pregnant women on gender preference, prenatal sex determination and female foeticide. Indian J Public Health. 2010;54:209-12.

13. Siddharam SM, Venktesh GM, Theshwari HL. Awareness regarding gender preference and female foeticide among teachers in the Hassan District, South India. J Clin Diagn Res. 2011;5(2):1430-3.

14. Khandelwal V, Chakole SV, Gupta H, Mehta SC. Gender preference, attitude and awareness regarding sex determination among married women attending general OPD \& Antenatal Clinic of RDGMC Ujjain, MP, India. Nat J Community Med. 2012;3(2):269-73.

Cite this article as: Dwivedi S, Gupta G, Kumari S, Sharma B. Study of association of sociodemographic characteristics with the knowledge about sex determination and preconception and prenatal diagnostic technique act among pregnant women. Int J Reprod Contracept Obstet Gynecol 2021;10:3164-8. 